\title{
Contribution of respiratory muscle oxygen consumption to breathing limitation and dyspnea
}

\author{
Pere Casan md, Carlos C Villafranca md, Clive Kearon mb bCh, \\ EDWARD JM CAMPBELL MD PhD, KIERAN J KILLIAN MB FRCPC FRCPI \\ Department of Medicine, McMaster University Medical Centre, Hamilton, Ontario
}

P CaSAN, CC Villafranca, C Kearon, EJM CAMPBELL, KJ KILLIAN. Contribution of respiratory muscle oxygen consumption to breathing limitation and dyspnea. Can Respir J 1997;4(2):101-107.

During exercise, the sustainable activity of large muscle groups is limited by oxygen delivery. The purpose of this study was to see whether the oxygen consumption of the respiratory muscles reaches a similar critical value under maximal resistive loading and hyperventilation. A secondary objective was to see whether dyspnea (estimated discomfort experienced with breathing using the Borg 0-10 scale) and the oxygen consumption of the respiratory muscles are closely related across conditions. This would be expected if intramuscular sensory nerve fibres stimulated as a consequence of metabolic events contributed to this sensation. In six normal subjects the respiratory muscles were progressively activated by the addition of incremental inspiratory resistive loads to a maximum of $300 \mathrm{~cm} \mathrm{H}_{2} 0 \times \mathrm{s} / \mathrm{L}$ $(\mathrm{SD}=66.4)$, and incremental dead space to a maximum of $2638 \mathrm{~mL}(\mathrm{SD}=452)$, associated with an increase in ventilation to $75.1 \mathrm{~L} / \mathrm{min}(\mathrm{SD}=29.79)$. Each increment was maintained for 5 mins to allow the measurement of oxygen uptake in a steady state. During resistive loading total oxygen consumption increased from $239 \mathrm{~mL} / \mathrm{min}(\mathrm{SD}=38.2)$ to $299 \mathrm{~mL} / \mathrm{min}(\mathrm{SD}=52.3)$ and dyspnea increased to 'very severe' (Borg scale 7.5, SD=1.55). During dead space loading total oxygen consumption increased from $270 \mathrm{~mL} / \mathrm{min}$ $(\mathrm{SD}=20.2)$ to $426 \mathrm{~mL} / \mathrm{min}(\mathrm{SD}=81.9)$ and dyspnea in- creased to 'very severe' $(7.1, \mathrm{SD}=0.66)$. Oxygen cost of inspiratory muscle power was $25 \mathrm{~mL} /$ watt $(95 \%$ confidence limits 16.7 to 34.3 ) with dead space loading and $91 \mathrm{~mL} /$ watt (95\% confidence limits 54 to 128) with resistive loading. Oxygen consumption did not reach a critical common value in the two types of loading, $60 \mathrm{~mL} / \mathrm{min}$ (SD 22.3) during maximal resistive loading and $156 \mathrm{~mL} / \mathrm{min}$ (SD 82.4) during maximal dead space loading $(\mathrm{P}<0.05)$. Physiological factors limiting the respiratory muscles are not uniquely related to oxygen consumption and appear to be expressed through the activation of sensory structures, perceptually manifested as dyspnea.

Key Words: Borg scale, Dead space loading, Hyperventilation, Resistive loading

\section{Contribution de la consommation d'oxygène des muscles respiratoires au manque de souffle et à la dyspnée}

RÉSUMÉ : Pendant l'exercice, l'activité soutenue des grands groupes musculaires est limitée par l'apport en oxygène. Le but principal de cette étude était de voir si la consommation d'oxygène des muscles respiratoires atteint une valeur critique similaire au cours d'une épreuve de charge résistive maximale et de l'hyperventilation. Un objectif secondaire de l'étude était de voir si la dyspnée (estimation de la gêne respiratoire avec l'échelle de Borg de 0 à 10) et la consommation d'oxygène des muscles respiratoires sont étroitement liés. On pourrait s'y attendre si les fibres nerveuses sensorielles intramusculaires stimulées à la suite 
d'événements métaboliques contribuaient à cette sensation. Chez 6 sujets sains, on a activé progressivement les muscles respiratoires en ajoutant progressivement des charges résistives à l'inspiration jusqu'à un maximum de $300 \mathrm{~cm} \mathrm{H}_{2} \mathrm{O} \times \mathrm{s} / \mathrm{L}$ (écart type 66,4), et en augmentant progressant l'espace mort jusqu'à un maximum de $2638 \mathrm{~mL}$ (écart type 452), associé à une augmentation de la ventilation jusqu'à 75,1 L/min (écart type 29,79). Chaque augmentation a été maintenue pendant 5 minutes pour permettre de mesurer l'absorption d'oxygène à l'état stable. Pendant l'épreuve de charge résistive, la consommation totale d'oxygène est passée de $239 \mathrm{~mL} / \mathrm{min}$ (écart type 38,2) à $299 \mathrm{~mL} / \mathrm{min}$ (écart type 52,3), et la dyspnée est devenue «très sévère» (7,5 sur l'échelle de Borg, écart type 1,55). Pendant l'épreuve de charge de l'espace mort, la consommation totale d'oxygène est passée de $270 \mathrm{~mL} / \mathrm{min}$ (écart type 20,2) à $426 \mathrm{~mL} / \mathrm{min}$ (écart type 81,9), et la dyspnée est devenue «très sévère» $(7,1$, écart type 0,66$)$. Le coût en oxygène de l'énergie musculaire à l'inspiration était de $25 \mathrm{~mL} /$ watt (limites de confiance $95 \%, 16,7-34,3$ ) avec l'épreuve de charge de l'espace mort et de $91 \mathrm{~mL} /$ watt (limites de confiance $95 \%, 54-128$ ) avec l'épreuve de charge résistive. La consommation en oxygène n'a pas atteint une valeur critique commune dans les deux types d'épreuve de charge, $60 \mathrm{~mL} / \mathrm{min}$ (écart type 22,3) pendant l'épreuve de charge résistive maximale et $156 \mathrm{~mL} / \mathrm{min}$ (écart type 82,4) pendant l'épreuve de charge de l'espace mort maximale $(\mathrm{P}<0,05)$. Les
$\mathrm{O}$ xygen delivery is believed to limit exercise performance because the mitochondrial capacity of muscle to consume oxygen vastly exceeds the capacity of the cardiorespiratory system to deliver oxygen (1-3). Maximal oxygen uptake ( $\mathrm{VO}_{2}$ max $)$ during exercise with large muscle groups varies to a limited extent with the mode of exercise, and is similar during cycle ergometry, treadmill exercise and stair climbing (4-6). Oxygen delivery is less compelling as a limiting factor to sustained activity with small muscle groups such as the respiratory muscles. However, studies of diaphragmatic bloodflow have indicated that a limitation in bloodflow contributes to diaphragmatic fatigue (7). The purpose of the present study was to determine whether oxygen consumption by the respiratory muscles reaches similar limiting values during two different types of maximal sustained breathing manoeuvres. The absence of a common critical value tends to refute a limitation in either oxygen delivery or the metabolic processes stoichiometrically expressed by oxygen consumption. A secondary objective was to see whether the intensity of dyspnea experienced in the two maximal breathing manoeuvres was uniquely related to the oxygen consumption of the respiratory muscles. In 1932, Harrison et al (8) considered dyspnea to be similar to claudication, and McIlroy (9) suggested that dyspnea occurred when the respiratory muscles developed an oxygen debt. Both suggestions implied that the metabolic activity of the respiratory muscles may reach a critical value at the limits of breathing performance and contribute to dyspnea through the direct stimulation of intramuscular sensory nerve fibers.

To measure dyspnea and the oxygen consumption of the respiratory muscles under sustained but close to maximal conditions, we took advantage of respiratory control which serves to preserve arterial gas and $\mathrm{pH}$ status substantially in the face of added resistive and dead space loads. Progressive loading was used to drive the respiratory muscles to limitation during high tension and low velocity contractions with imposed resistances, and during both high tension and high velocity contractions with dead space loading.

\section{PATIENTS AND METHODS}

Subjects: Studies were carried out in six normal subjects (three males and three females) ranging from 28 to 42 years of age, who had previous experience with respiratory studies but did not know the purpose of the experiment (Table 1).
Spirometric indexes of vital capacity and forced expiratory volume in one second $\left(\mathrm{FEV}_{1}\right)$ and the maximal inspiratory pressure were normal $(10,11)$. All participants gave informed consent following a detailed description of the studies.

Apparatus and measurements: The inspiratory resistance circuit consisted of a perforated brass tube covered with filter paper calibrated to provide a wide range of resistances. By moving the plunger in the tube, resistive loads $(40,64,96$, $128,168,232,272,332,400 \mathrm{~cm} \mathrm{H}_{2} \mathrm{O} \times \mathrm{s} / \mathrm{L}$ ) could be applied, as described previously (9). Dead space loading was achieved by adding a series of rigid tubes of $34 \mathrm{~mm}$ internal diameter between the mouthpiece and the unidirectional valve resulting in 75, 700, 1400, 1900 and $2900 \mathrm{~mL}$ of added dead space. A Hans Rudolph No 2700 nonrebreathing twoway valve (Missouri) was used for dead space loading; during resistive loading the valve leaflets of this unidirectional valve prolapsed, and a Hans Rudolph No 1400 was used. Mouth pressure $\left(\mathrm{P}_{\mathrm{m}}\right)$ was measured using a differential pressure transducer (Hewlett-Packard No 267, Massachusetts). Inspiratory (TI) and expiratory time were obtained from the $\mathrm{P}_{\mathrm{m}}$ trace. End tidal carbon dioxide $\left(\mathrm{PETCO}_{2}\right)$ was measured at the mouth using an infrared capnograph (AMETEK-P61B, California). Arterial oxygen saturation $\left(\mathrm{SaO}_{2}\right)$ and heart rate were measured with an ear oximeter (BTI BIOX III, Colorado). All the signals were displayed on an eight channel polygraph recorder (Hewlett-Packard 7758A). Minute ventilation ( $\left.\dot{V}_{E}\right)$, tidal volume (VT), frequency of breathing and oxygen uptake $\left(\dot{\mathrm{V}}_{2}\right)$ were measured using an automated Universal Exercise System (MMC Horizon, SensorMedics, California), calibrated as described previously (13). This system incorporates a turbine with electro-optical detectors for measurement of $\dot{V}_{E}$ and a mixing chamber with polarographic and infrared gas analyzers to measure the mixed expired oxygen and carbon dioxide. The standard equation for the measurement of $\dot{\mathrm{VO}}_{2}$ was used:

$$
\dot{\mathrm{VO}}_{2}=\dot{\mathrm{V}}_{\mathrm{E}}(\mathrm{STPD}) \cdot\left[\left(\mathrm{FIO}_{2}\right) \bullet\left(1-\mathrm{FEO}_{2}-\mathrm{FECO}_{2}\right) /\left(1-\mathrm{FIO}_{2}-\mathrm{FICO}_{2}\right)-\mathrm{FEO}_{2}\right]
$$

where STPD is standard temperature and pressure dry; $\mathrm{FiO}_{2}$ is fraction of inspired oxygen; $\mathrm{FiCO}_{2}$ is the fraction of inspired carbon dioxide; $\mathrm{FEO}_{2}$ is fraction of expired oxygen; and $\mathrm{FECO}_{2}$ is fraction of expired carbon dioxide.

Discomfort experienced and associated with the act of breathing (dyspnea) was measured using the Borg 0-10 scale (14). This is a category scale in which the subject is free to 
TABLE 1

Anthropometric and pulmonary function measurements of six subjects

\begin{tabular}{lcccccc}
\hline Patient & Sex & Age (years) & Weight $\mathbf{( k g )}$ & Height (cm) & $\begin{array}{c}\text { Forced expiratory volume } \\
\text { in 1 s (L) }\end{array}$ & $\begin{array}{c}\text { Maximal inspiratory } \\
\left.\text { pressure (cm } \mathbf{H}_{\mathbf{2}} \mathbf{O}\right)\end{array}$ \\
\hline 1 & Female & 28 & 61 & 162 & 3.05 & 135 \\
2 & Female & 29 & 60 & 168 & 3.25 & 80 \\
3 & Female & 33 & 61 & 159 & 3.16 & 88 \\
4 & Male & 28 & 66 & 175 & 3.98 & 100 \\
5 & Male & 35 & 70 & 168 & 3.76 & 140 \\
6 & Male & 42 & 70 & 178 & 3.93 & 160 \\
& Mean \pm SD & $33 \pm 5.5$ & $65 \pm 4.6$ & $168 \pm 7.3$ & $3.52 \pm 0.415$ & $117 \pm 32.3$ \\
\hline
\end{tabular}

TABLE 2

Inspiratory resistance at rest and maximal, added dead space at rest and maximal

\begin{tabular}{|c|c|c|c|c|}
\hline & \multicolumn{2}{|c|}{ Inspiratory resistance ( $\left.\mathrm{cm} \mathrm{H}_{2} \mathrm{O} \times \mathrm{s} / \mathrm{L}\right)$} & \multicolumn{2}{|c|}{ Added dead space (mL) } \\
\hline & $\begin{array}{c}\text { Rest } \\
\text { mean (SD) }\end{array}$ & $\begin{array}{c}\text { Maximal } \\
\text { mean (SD) }\end{array}$ & $\begin{array}{c}\text { Rest } \\
\text { mean (SD) }\end{array}$ & $\begin{array}{c}\text { Maximal } \\
\text { mean (SD) }\end{array}$ \\
\hline Peak inspiratory pressure $\left(\mathrm{cm} \mathrm{H}_{2} \mathrm{O}\right)$ & $9.1(1.94)(\mathrm{ns})$ & $64.0(12.4)^{t \dagger}$ & $9.6(1.55)^{\ddagger}$ & $44.8(13.9)^{\S}$ \\
\hline Inspiratory work (W) & $0.08(0.030)(\mathrm{ns})$ & $0.55(0.210)^{\dagger \dagger}$ & $0.09(0.031)^{\ddagger}$ & $4.47(3.17)^{\S}$ \\
\hline Mouth pressure $\left(\mathrm{cm} \mathrm{H}_{2} \mathrm{O}\right)$ & $1.5(0.84)(\mathrm{ns})$ & $52.0(9.57)^{\dagger \dagger}$ & $1.0(0)(\mathrm{ns})$ & $3.0(2.28)^{\S \S}$ \\
\hline Ventilation (L) & $7.4(1.81)^{\star}$ & $6.8(1.57)(\mathrm{ns})$ & $8.6(1.64)^{\ddagger \ddagger}$ & $75.1(29.79)^{\S \S}$ \\
\hline Mean inspiratory flow $\mathrm{V}_{\mathrm{T}} / \mathrm{T}_{\mathrm{I}}(\mathrm{L} / \mathrm{s})$ & $0.33(0.098)(\mathrm{ns})$ & $0.18(0.043)^{\dagger \dagger}$ & $0.35(0.043)^{\ddagger \ddagger}$ & $3.06(1.261)^{\S \S}$ \\
\hline Duty cycle & $0.37(0.056)(\mathrm{ns})$ & $0.66(0.142)^{\dagger \dagger}$ & $0.41(0.046)(n s)$ & $0.42(0.034)^{\S \S}$ \\
\hline Arterial oxygen saturation (\%) & $97(1.7)(\mathrm{ns})$ & $97(1.8)(\mathrm{ns})$ & $98(1.4)^{\ddagger}$ & $85(9.4)^{\S \S}$ \\
\hline End tidal carbon dioxide $(\mathrm{mmHg})$ & $36(8.4)(\mathrm{ns})$ & $41(4.7)(\mathrm{ns})$ & $37(3.1)^{\ddagger \ddagger}$ & $50(3.7)^{\S \S}$ \\
\hline Oxygen uptake (mL/min) & $239(38.2)^{*}$ & $299(52.3)(n s)$ & $270(20.2)^{\ddagger \ddagger}$ & $426(81.9)^{\S \S}$ \\
\hline Heart rate (beats/min) & 65 (10.5) (ns) & $75(12.1)(\mathrm{ns})$ & $70(12.6)^{\ddagger}$ & $92(9.3)^{\S \S}$ \\
\hline
\end{tabular}

${ }^{*}$ Resting resistance versus resting dead space $(P<0.05) ;{ }^{t \dagger}$ Resting resistance versus maximal resistance $(P<0.01) ;{ }^{\ddagger}$ Resting dead space versus maximal dead space $(P<0.05) ;{ }^{\ddagger}$ Resting dead space versus maximal dead space $(P<0.01)$; ${ }^{\S}$ Maximal resistance versus maximal dead space $(P<0.05) ;{ }^{\S}$ Maximal resistance versus Maximal dead space $(P<0.01)$. ns Not significant

select a number tagged to descriptive phrases that reflect respiratory discomfort: 0 denotes no appreciable dyspnea and 10 denotes maximum discomfort in breathing. Rating was performed during the last minute of each load.

General procedures: Subjects were seated in a comfortable chair and were requested to relax and to avoid any extraneous muscular activity. A brief period was allowed for adaptation to the circuit. The experiment began with 20 mins of resting ventilation at the end of which $\dot{\mathrm{V}}_{\mathrm{E}}, \dot{\mathrm{V}}_{2}$ and expired gas composition varied by less than 5\%. Following this the respiratory loads, inspiratory resistance or dead space were added in random order. The subjects were not informed before changes in load, and the loading circuit was out of the subject's sight. Each condition was maintained for 5 mins, and $\dot{\mathrm{V}}_{\mathrm{E}}, \dot{\mathrm{V}} \mathrm{O}_{2}$, carbon dioxide output $\left(\dot{\mathrm{V}} \mathrm{CO}_{2}\right)$ and the intensity of dyspnea were measured during the last minute of each $5 \mathrm{~min}$ period. After 5 mins the load was increased until the subject failed to complete the period. At limitation, oxygen uptake at the mouth did not reflect oxygen consumption in the muscles; hence, if the load was not completed the values of the previous load were used for calculation of $\dot{\mathrm{VO}}_{2}$.

Analysis of results: Oxygen consumption of the respiratory muscles ( $\dot{\mathrm{V}} \mathrm{O}_{2}$ resp) was derived by subtraction of basal oxygen consumption from the measured maximal oxygen con- sumption. Maximam oxygen consumption of the respiraotry muscles ( $\dot{\mathrm{V}}_{2}$ resp max $)$ during maximal resistive loading and maximal dead space loading was compared using Student's paired $t$ test. The submaximal relationships between oxygen uptake and added resistance, dyspnea and oxygen consumption and other similar variables were analyzed using both linear regression analysis and multiple linear regression analysis. Multiple linear regression analysis was performed following the introduction of dummy variables to identify and treat individual subjects as covariates to control for the variability across subjects (15). Where multiple regression analysis was used following the introduction of the dummy variables, the coefficients associated with each subject were omitted from the reported regression equations. Regression of $\dot{\mathrm{VO}}_{2}$ resp versus ventilation was performed assuming a resting $\dot{\mathrm{V}} \mathrm{O}_{2}$ resp of $0.5 \mathrm{~mL}$ oxygen/L ventilation. Both $\dot{\mathrm{VO}}_{2}$ resp and $\dot{V}_{E}$ were logarithmically transformed because the oxygen costs of breathing increase in an alinear manner with increasing ventilation, yielding an equation of the form:

$$
\dot{\mathrm{V}} \mathrm{O}_{2}=\text { constant } \bullet \dot{\mathrm{V}}^{\mathrm{b}}
$$

The mechanical indexes of peak inspiratory pressure ( $\mathrm{P}_{\text {insp peak }}$, pressure/time product (PTP) and inspiratory work $(\mathrm{PTP} \times \mathrm{VT} / \mathrm{TI})$ were estimated. The measured values at 


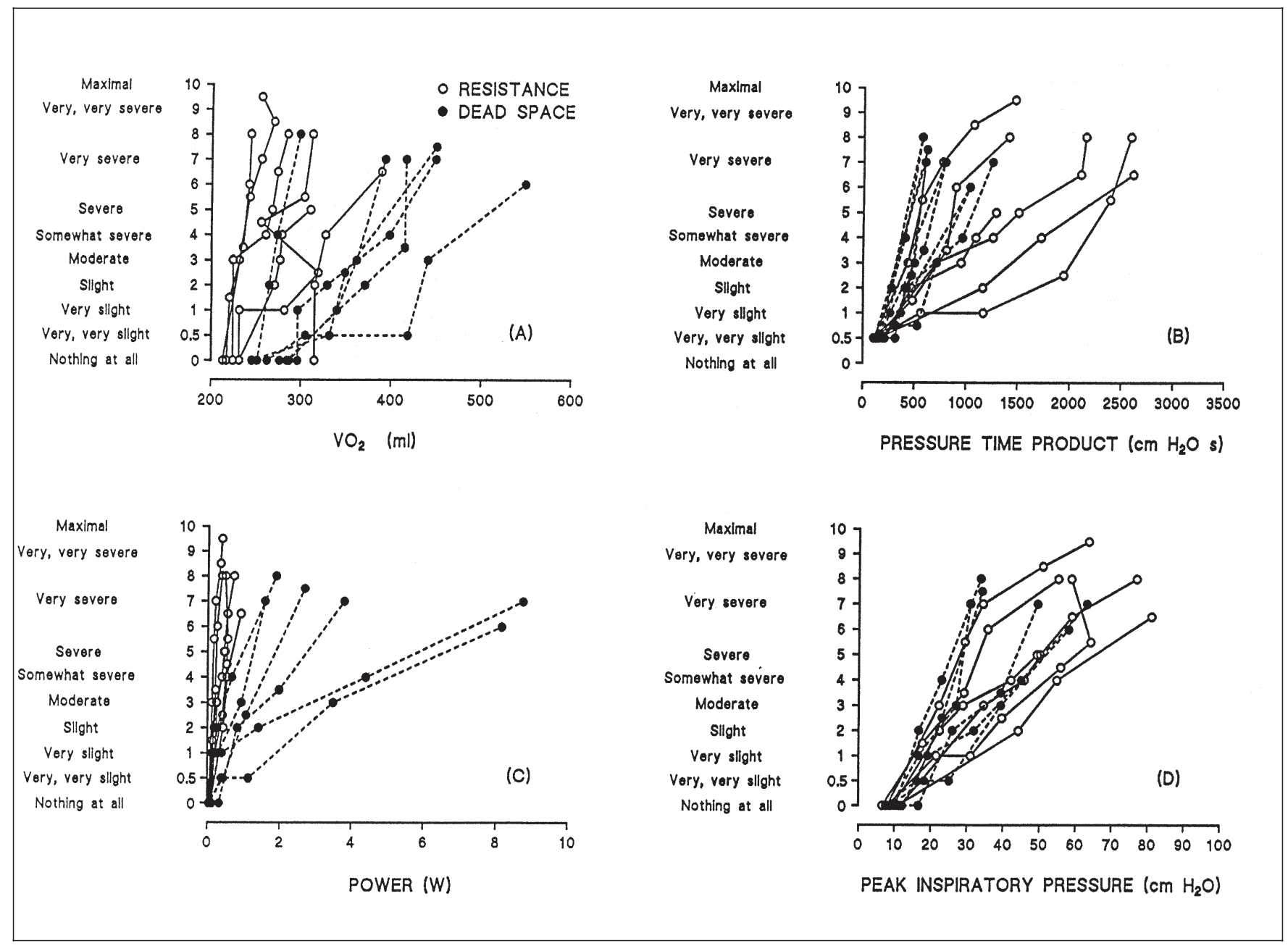

Figure 1) Individual estimates of dyspnea using the Borg Scale under conditions of resistive (open circles) and dead (closed circles) space loading with $\mathbf{( A )}$ rising levels of oxygen uptake ( $\left.\mathrm{VO}_{2}\right)$; (B) pressure/time product; (C) power; and (D) peak inspiratory pressure

the mouth were added to the values calculated to overcome the elastance and resistance of the respiratory system. The elastance of the respiratory system was taken as $14 \mathrm{~cm} \mathrm{H}_{2} \mathrm{O} / \mathrm{L}$ and resistive pressure was taken as:

$$
1.92 \bullet \mathrm{V}_{\mathrm{T}} / \mathrm{T} \mathrm{I}+0.52 \bullet\left(\mathrm{VT} / \mathrm{T}_{\mathrm{I}}\right)^{2}
$$

These values were taken from D'Angelo et al (16). Inspiratory flow was taken as rectangular assuming a value equal to VT/TI (17). Peak pressure was assumed to occur following $80 \%$ of the inspired volume:

$$
\mathrm{P}_{\text {insp peak }}=\mathrm{P}_{\mathrm{m}}+0.8 \bullet \mathrm{VT} \bullet 14+1.92 \bullet \mathrm{VT} / \mathrm{T}_{\mathrm{I}}+0.52 \bullet\left(\mathrm{VT} / \mathrm{T}_{\mathrm{I}}\right)^{2}
$$

The contributions of viscoelastance and distortion to pressure, PTP and power were omitted.

\section{RESULTS}

Resistive loading: $\mathrm{VO}_{2}$ increased from a resting value of $239 \mathrm{~mL} / \mathrm{min}(\mathrm{SD}=38.2)$ to $299 \mathrm{~mL} / \mathrm{min}(\mathrm{SD}=52.3)$ with a maximal added resistance of $300 \mathrm{~cm} \mathrm{H}_{2} \mathrm{O} \times \mathrm{s} / \mathrm{L}(\mathrm{SD}=66.4)$. There was a small decrease in $\dot{V}_{E}$ from $7.4 \mathrm{~L} / \mathrm{min}$ to 6.8 $\mathrm{L} / \mathrm{min}$, and $\mathrm{P}$ insp peak increased from $9.1 \mathrm{~cm} \mathrm{H}_{2} \mathrm{O}$ to $64.0 \mathrm{~cm}$
$\mathrm{H}_{2} \mathrm{O}$ (Table 2). The estimated power output of the inspiratory muscle increased from $0.08 \mathrm{~W}(\mathrm{SD}=0.03)$ to $0.55 \mathrm{~W}$ $(\mathrm{SD}=0.21)$ with an oxygen consumption of $60 \mathrm{~mL} / \mathrm{min}$ $(\mathrm{SD}=22.3)$ (Table 2), an oxygen cost of $91 \mathrm{~mL} / \mathrm{W}(95 \%$ confidence interval 54 to 8$). \mathrm{SaO}_{2}$ and $\mathrm{PETCO}_{2}$ did not change during resistive loading (Table 2).

Dead space loading: $\mathrm{VO}_{2}$ increased from a resting value of $270 \mathrm{~mL} / \mathrm{min}(\mathrm{SD}=20.2)$ to $426 \mathrm{~mL} / \mathrm{min}(\mathrm{SD}=81.9)$ with a maximal added dead space of $2638 \mathrm{~mL}(\mathrm{SD}=451.9)$. $\dot{\mathrm{V}}_{E}$ increased from 8.6 to $75.1 \mathrm{~L} / \mathrm{min}$, and Pinsp peak increased from 9.6 to $44.8 \mathrm{cmH}_{2} \mathrm{O}$ (Table 2). The estimated power output of the inspiratory muscles increased from $0.09 \mathrm{~W}$ $(\mathrm{SD}=0.03)$ to $4.47 \mathrm{~W}(\mathrm{SD}=3.17)$ with an oxygen consumption of $156 \mathrm{~mL} / \mathrm{min}(\mathrm{SD}=82.4)$ (Table 2). Oxygen cost was $25 \mathrm{~mL} / \mathrm{W}$ (95\% confidence interval 16.7 to 34.3 ). $\mathrm{SAO}_{2}$ fell from $98 \%$ to $86 \%$, and $\mathrm{PETCO}_{2}$ increased from $37 \mathrm{mmHg}$ to $50 \mathrm{mmHg}$ with the highest dead space load (Table 2).

Dyspnea, oxygen consumption and respiratory mechanics: Dyspnea increased to a maximal intensity of "very severe', 7.5 during resistive loading $(\mathrm{SD}=1.55)$, and to 'very severe', 7.1 during dead space loading $(\mathrm{SD}=0.66)(2638 \mathrm{~mL}$, $\mathrm{SD}=451.9 \mathrm{~mL}$ ). The intensity of dyspnea was significantly 
related to $2(\mathrm{P}<0.0001)$, $\mathrm{PTP}\left(\mathrm{cm} \mathrm{H}_{2} \mathrm{O} \times \mathrm{s}\right)(\mathrm{P}<0.0001)$, power output (watts) $(\mathrm{P}<0.0001)$ and $\mathrm{P}_{\text {insp peak }}\left(\mathrm{cm} \mathrm{H}_{2} \mathrm{O}\right)$ $(\mathrm{P}<0.0001)$ (Figure 1). In all four relationships dyspnea was greater during resistive loading than during dead space loading ( $\dot{\mathrm{V}} \mathrm{O}_{2}$ resp $\mathrm{P}<0.0001$; $\mathrm{PTP} \mathrm{P}<0.05$; power output $\mathrm{P}<0.001$; $\mathrm{P}_{\max }$ insp $\left.\mathrm{P}<0.10\right)$. The mechanical variable most closely

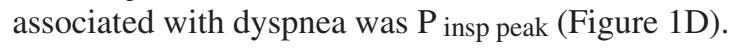

\section{DISCUSSION}

$\dot{\mathrm{V}} \mathrm{O}_{2}$ resp max may be determined by a limitation in oxygen delivery to respiratory muscles or merely reflect the sum of unit processes involved in aerobic metabolism in a stoichiometric manner. In the present study the oxygen consumption reached at, or very close to, the point of limitation was not the same during the two types of respiratory loading. Respiratory muscle oxygen consumption was $60 \mathrm{~mL} / \mathrm{min}$ $(\mathrm{SD}=22.3)$ and power output $0.55 \mathrm{~W}(\mathrm{SD}=0.21)$ during maximal resistive loading was substantially lower than during maximal dead space loading, in which 2 resp max was 156 $\mathrm{mL} / \mathrm{min}(\mathrm{SD}=82.4)$ and power $4.47 \mathrm{~W}(\mathrm{SD}=3.17)$. The difference in $\dot{\mathrm{VO}}_{2}$ resp max was so great that it is difficult to regard respiratory muscle oxygen delivery or aerobic metabolism as limiting in both types of respiratory loading. Although both loads were accompanied by similar intensity of dyspnea, dead space loading was associated with a greater capacity to perform work and higher energy expenditure and oxygen consumption. This was most likely due to the higher velocity and extent of respiratory muscle contraction with higher rates of actin and myosin cross bridging in dead space loading.

While oxygen delivery or consumption did not limit, it was also apparent that power output or PTP did not reach similar critical limiting values at limitation. Although a case might be made in favour of peak pressure as limiting, this variable also was not significantly different at limitation $(\mathrm{P}=0.10)$. Because the intensity of dyspnea was similar at limitation with both types of loading, a case can be made for sensory limitation expressed through the generation of dyspnea.

Oxygen uptake reflects only aerobic metabolism and at the point of limitation it is difficult to exclude anaerobic metabolism and its consequences as a limiting factor. Short periods of high intensity activity can be performed with selective recruitment of fast twitch motor units, in which intramuscular energy stores of adenosine triphosphate, creatine phosphate and the production of lactate from glycolysis may account for an appreciable proportion of the energy needs. However, the generation of substantial energy from these sources is unlikely to apply to a load maintained for 5 mins, as in the present study. Anaerobic metabolism may have occurred during the final load, which was usually sustained for only a few breaths. Even the contribution of anaerobic processes to limitation are likely to be expressed through the activation of sensory receptors contributing to discomfort, in turn limiting further activity.

The large differences in oxygen uptake observed between resistive and dead space loading in the present study are unlikely to have been due to technical errors, but these should be considered. Oxygen uptake continues to increase with time during high intensity muscular activity (18) such that steady state conditions are only strictly achieved during low intensity activity, but the $5 \mathrm{~min}$ duration of each load increment should have ensured a steady enough state for the measurements of oxygen uptake to be valid. Furthermore, this effect and the effect of any extraneous muscle activity would be expected to influence measurements in both types of incremental loading, in which oxygen uptake increased systematically. Liljestrand (19) showed that activation of the normal control processes was essential for reproducible measurement of the oxygen cost of breathing, with voluntary hyperventilation leading to unreliable measurements because of inefficient activation of respiratory and other muscles. Errors in the measurement of the oxygen cost of breathing historically have been a matter of concern (20-25). Reliability has been an issue because with the hyperventilation of ventilatory loading, the inspired to expired oxygen difference is small; errors in the measurement of $\mathrm{FEO}_{2}$ lead to large errors in calculated oxygen consumption. Because of these concerns $\mathrm{FEO}_{2}$ was measured simultaneously in the present study by two independent techniques, polarographic electrode and mass spectrometry, both calibrated by the same test gases. The values of $\mathrm{FEO}_{2}$ were highly correlated, with $r=0.98$ and a slope close to unity (0.97, intercept 0.003$)$; these results are similar to a previous comparison of these methods during exercise (13). For these reasons, although care with the experimental protocol and precision of analysis are critical, the measurements of oxygen uptake in the present study appear to be valid, and analytical errors are unlikely to have accounted for the large differences in between the two types of loading.

In the present study the oxygen cost of breathing increased in a positively accelerating manner with ventilation:

$$
\dot{\mathrm{V}} \mathrm{2}_{\text {resp }}=0.12 \bullet \dot{\mathrm{V}} \mathrm{E}^{1.7} \quad(\mathrm{r}=0.95, \mathrm{P}<0.0001)
$$

This relationship indicates that $\dot{\mathrm{V}}_{2}$ resp increases from $6 \mathrm{~mL} / \mathrm{min}$ at $10 \mathrm{~L} / \mathrm{min}(0.6 \mathrm{~mL} / \mathrm{L})$, to $20 \mathrm{~mL} / \mathrm{min}$ at $20 \mathrm{~L} / \mathrm{min}$ (1 $\mathrm{mL} / \mathrm{L}), 63 \mathrm{~mL} / \mathrm{min}$ at $40 \mathrm{~L} / \mathrm{min}(1.6 \mathrm{~mL} / \mathrm{L})$ and 206 $\mathrm{mL} / \mathrm{min}$ at $80 \mathrm{~L} / \mathrm{min}(2.6 \mathrm{~mL} / \mathrm{L})$ of ventilation. With the maximal added dead space the oxygen consumed by the respiratory muscles was $151 \mathrm{~mL} / \mathrm{min}$ at a ventilation of $75 \mathrm{~L} / \mathrm{min}$. These values for the oxygen cost of increased breathing are virtually the same as in the carefully conducted studies of Liljestrand in 1918 (19). With maximal resistive breathing the oxygen consumed by the respiratory muscles was $60 \mathrm{~mL} / \mathrm{min}$ and ranged from 26 to $79 \mathrm{~mL} / \mathrm{min}$ at the maximal added resistance tolerated. These results are also similar to those previously reported $(23,26)$. The substantial differences between $\dot{\mathrm{VO}}_{2}$ resp measured under the two types of conditions are probably explained in terms of the differing relationships among tension, length and velocity of muscle contraction. With maximal breathing efforts in resistive loading, tension is high, velocity is low and changes in length are small; in dead space loading, tension is lower, velocity higher and large changes in length accompany the large tidal volumes employed. Power output of muscle is the product of 
tension and velocity, and the muscle's greatest capacity to perform external work occurs in conditions of low tension with high velocity and large changes in length (27-31). Thus, in ventilatory loading imposed by added dead space, the higher maximum $\dot{\mathrm{V}} \mathrm{O}_{2}$ resp is explained by low tension and high velocity contractions of respiratory muscles generating high tidal volumes at high frequency; the lower maximum $\dot{\mathrm{V}} \mathrm{O}_{2}$ resp in resistive loading are associated with the contractile conditions of high tension and low velocity, with small tidal volumes and low breathing frequencies.

The idea that limitation was imposed by the sensory consequences of respiratory muscle activity does not address the physiological processes contributing to sensory receptor stimulation and, thus, contributing to dyspnea. The intensity of dyspnea was the same at discontinuation for the two conditions of loaded breathing. Strictly considered, the final loads were submaximal, and maximal symptom ratings of 10 on the Borg scale were not seen, but submaximal symptom ratings at the limits of human muscular performance are often seen because subjects are unwilling to tolerate maximal discomfort $(32,35)$. Locally produced mediators in the respiratory muscles including potassium ions, adenosine, prostaglandins, lactate and changes in osmolarity effectively achieve a match between metabolism and muscle bloodflow (36-41). These mediators may also stimulate sensory nerve endings and contribute to a sense of muscular discomfort and dyspnea. If mediators released in a stoichiometric relationship to metabolism stimulated free nerve endings and contribute to dyspnea, the sensory intensity of dyspnea might be broadly similar to oxygen consumption across contractile conditions. The results of the present study refute this simple hypothesis. Many other sensory inputs have been postulated to contribute to dyspnea including central motor output that is associated with a sense of effort, afferent activity from muscle spindles and tendon organs that is associated with

\section{REFERENCES}

1. Wagner PD, Hoppeler H, Saltin B. Determinants of maximal oxygen uptake. In: Crystal RG, West JB, eds. The Lung. Scientific Foundations, vol II. New York: Raven Press, 1991:1585-93.

2. Andersen P, Saltin B. Maximal perfusion of skeletal muscle in man. J Appl Physiol 1985;366:233-49.

3. Rowell LB, Saltin B, Kiens B, Christensen NJ. Is peak quadriceps blood flow in humans even higher during exercise with hypoxemia? Am J Physiol 1986;251:H1038-44.

4. Astrand P, Rodahl R. Physical performance. In: Van Dalen DB, ed. Textbook of Work Physiology. Physiological Bases of Exercise. New York: McGraw-Hill International Editions, 1986:295-353.

5. Lange Andersen K, Shephard RJ, Denolin H, Varnauskas E, Masironi R. Fundamentals of Exercise Testing. Geneva: World Health Organization, 1971:119-23.

6. Glassford RG, Baycroft GHY, Sedgewick AW, MacNab RBJ. Comparison of maximal oxygen uptake values determined by predicted and actual methods. J Appl Physiol 1965;20:509-13.

7. Bellemare F, Wight D, Lavigne CM, Grassino A. Effect of tension and timing of contraction on the blood flow of the diaphragm. J Appl Physiol 1983;54:1598-606.

8. Harrison TR, Harrison WG, Calhoun JA, Marsh JP. Congestive heart failure. XVII. The mechanism of dyspnea on exertion. Arch Intern Med 1932;50:690-720.

9. McIlroy MB. Dyspnea and the work of breathing in diseases of the heart and lungs. Prog Cardiovasc Dis 1958;1:284-97.

10. Black LF, Hyatt RE. Maximal respiratory pressures: Normal values and relationship to age and sex. Am Rev Respir Dis 1969;99:696-702. perceived force and displacement, and chemoreceptor stimulation generating an increased and uncomfortable urge to breathe (42). Central motor output results in a sense of effort and may determine the magnitude of dyspnea. The other sensory structures such as tendon organs, muscle spindles, joint receptors and perhaps chemoreceptors are sentient and may influence the quality of the resulting sensation (43-46). The magnitude of dyspnea in the present study would increase as a function of the motor output (effort) required to generate a ventilation or to maintain ventilation in the face of increasing resistance. Chemoreceptor stimulation appears to generate an unpleasant urge to breathe and may contribute to dyspnea independent of effort. The increased chemoreceptor activity caused by hypercapnia and desaturation may have contributed in part to the dyspnea experienced during dead space loading.

The absence of the simple relationship sought between respiratory muscle oxygen consumption and dyspnea does not exclude an indirect role for respiratory muscle metabolism in contributing to dyspnea. Changes in metabolism affecting membrane polarization, electromechanical coupling and calcium release modify the responsiveness of the respiratory muscle to alpha motor stimulation. Also, the inherent excitability of the alpha motor neurone may itself be reflexly inhibited by free nerve endings stimulated as a consequence of mediator release.

In summary, no finite critical limiting value in oxygen consumption was observed when the respiratory muscles were driven to limitation during resistive and dead space loading. The intensity of discomfort reached a critical and finite limiting value but its relationship to oxygen consumption by the respiratory muscle appears to be variable and indirect.

ACKNOWLEGEMENTS: This work was supported by the Medical Research Council of Canada.
11. Crapo RO, Morris AH, Gardner RM. Reference spirometric values using techniques and equipment that meet ATS recommendations. Am Rev Respir Dis 1981;123:659-64.

12. Killian KJ, Bucens DD, Campbell EJM. Effect of breathing patterns on the perceived magnitude of added loads to breathing. J Appl Physiol 1982;52:578-84.

13. Jones NL. Evaluation of a microprocessor controlled exercise testing system. J Appl Physiol 1984;57:1312-8.

14. Borg GAV. Psychophysical bases of perceived exersion. Med Sci Sports Exerc 1982;14:377-81.

15. Kleinbaum DG, Kupper LL, Muller KE. Dummy variables in regression. In: Payne M, ed. Applied Regression Analysis and Other Multivariable Methods. Boston: PWS-Kent Publishing Co, 1988:260-81.

16. D’Angelo E, Calderini E, Torri G, Robatto F, Bono D, Milic-Emili J. Respiratory mechanics in anesthetized paralyzed humans: effects of flow, volume, and time. J Appl Physiol 1989;67:2556-64.

17. Lafortuna CL, Minetti AE, Mognoni P. Inspiratory flow pattern in humans. J Appl Physiol 1984;57:1111-9.

18. Kearon MC, Summers E, Jones NL, Campbell EJM, Killian KJ. Breathing during prolonged exercise in man. J Physiol 1991;442:477-87.

19. Liljestrand G. Studies of the work of breathing. (Untersuchungen über die Atmungsarbeit. Scand Arch Physiol 1918;35:199-293). Reprinted in West JB, ed. Translations in Respiratory Physiology. Pennsylvania: Dowden, Hutchinson \& Ross Inc, 1975:438-513. 
20. Bartlett RG, Brubach HF, Specht H. Oxygen cost of breathing. J Appl Physiol 1958;12:413-24.

21. Campbell EJM, Westlake EK, Cherniack RM. Simple methods of estimating oxygen consumption and efficiency of the muscles of breathing. J Appl Physiol 1957;11:303-8.

22. Campbell EJM, Westlake EK, Cherniack RM. The oxygen consumption and efficiency of the respiratory muscles of young male subjects. Clin Sci 1959;18:55-64.

23. Jones GL, Killian KJ, Summers E, Jones NL. Inspiratory muscle forces and endurance in maximum resistive loading. J Appl Physiol 1985;58:1608-15.

24. Milic-Emili J. Work of Breathing. In: West JB, Crystal RG, eds. The Lung. Scientific Foundations, vol I. New York: Raven Press, 1991:1065-75.

25. Milic-Emili J, Petit JM. Mechanical efficiency of breathing. J Appl Physiol 1960;15:359-62.

26. Collett PW, Perry C, Engel LA. Pressure-time product, flow, and oxygen cost of resistive breathing in humans. J Appl Physiol 1985;58:1263-72.

27. Carlson FD. Kinematic studies in mechanical properties of muscle. In: Remington JW, ed. Tissue Elasticity. Washington: American Physiological Society, 1957.

28. Fenn WO. The relation between the work performed and the energy liberated in muscular contraction. J Physiol 1923;58:373-95.

29. Fenn WO, Marsh BS. Muscular force at different speeds of shortening. J Physiol 1935;85:277-97.

30. Hill AV. The heat of shortening and the dynamic constraints of muscle. Proc R Soc Lond (Biol) 1938;126:136-95.

31. Kushmerick MJ, Davies RE. The chemical energetics of muscle contraction. II. The chemistry, efficiency and power of maximally working sartorius muscle. Proc R Soc Lond (Biol) 1969;174:315-53.

32. Jones NL, Kearon MC, Leblanc P, Martin DH, Campbell EJM, Killian KJ. Symptoms limiting activity in chronic airflow limitation. Am Rev Respir Dis 1989;139:A319. (Abst)

33. Jones NL, Killian KJ. Limitation of exercise in chronic airway obstruction. In: Cherniack NS, ed. Chronic Obstructive Pulmonary Disease. Philadelphia: WB Saunders Co, 1991:196-206.

34. Killian KJ. The measurement and interpretation of exercise-induced symptoms: Dyspnea or breathlessness. In: Oldridge NB, Foster C,
Schmidt DH, eds. Cardiac Rehabilitation \& Clinical Exercise Programs: Theory \& Practice. Ithaca: Mouvement Publications Inc, 1988:65-78.

35. Killian KJ, Leblanc P, Martin DH, Summers E, Jones NL, Campbell EJM. Exercise capacity and ventilatory, circulatory, and symptom limitation in patients with chronic airflow limitation. Am Rev Respir Dis 1992;146:935-40.

36. Gaskell WH. On the tonicity of the heart and blood vessels. J Physiol (Lond) 1880;3:48-75.

37. Gorman MW, Kelley SS, Kaiser L, Sparks HV. Purinergic control of skeletal muscle blood flow. In: Phillis JW, ed. Adenosine and Adenine Nucleotides as Regulators of Cellular Function. Boca Raton: CRC Press, 1991.

38. Gorman MW, Sparks HV. The unanswered question. News Physiol Sci 1991;6:191-3.

39. Honig CR. Contributions of nerves and metabolites to exercise vasodilation: A unifying hypothesis. Am J Physiol 1979;236:H705-19.

40. Rochester DF. Respiratory muscle blood flow and metabolism. In: Roussos C, Macklem PT, eds. The Thorax. (Part A). New York: Marcel Dekker Inc, 1985:393-436.

41. Shepherd JT. Circulation to skeletal muscle. In: Anonymous Handbook of Physiology. The Cardiovascular System. Peripheral Circulation and Organ Blood Flow. Bethesda: American Physiology Society, 1983:319-70.

42. Altose MD, Cherniack NS, Fishman AP. Respiratory sensations and dyspnea: Perspectives. J Appl Physiol 1985;58:1051-4.

43. Killian KJ. Breathlessness - The sense of respiratory muscle effort. In: Borg G, Ottoson D, eds. The Perception of Exertion in Physical Work. Wenner-Gren International Symposium Series. London: The Macmillan Press Ltd, 1986:71-82.

44. Killian KJ. The Nature of Breathlessness and its Measurement. In: Jones NL, Killian KJ, eds. Breathlessness 1991. Proceedings of the Campbell Symposium held in Hamilton, Ontario, May 1991. Hamilton: Decker Medical Publications, 1992:74-87.

45. Killian KJ, Campbell EJM. Mechanisms of dyspnea. In: Mahler DA, ed. Dyspnea. Mount Kisco: Futura Publishing Co, 1990:55-73.

46. Killian KJ, Campbell EJM. Dyspnea. In: Crystal RG, West JB, eds. The Lung: Scientific Foundations. New York: Raven Press Ltd, 1991:1433-43. 


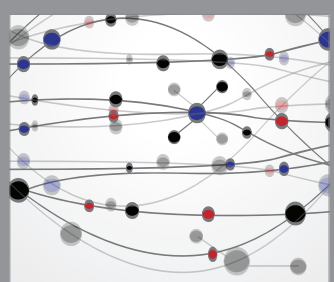

The Scientific World Journal
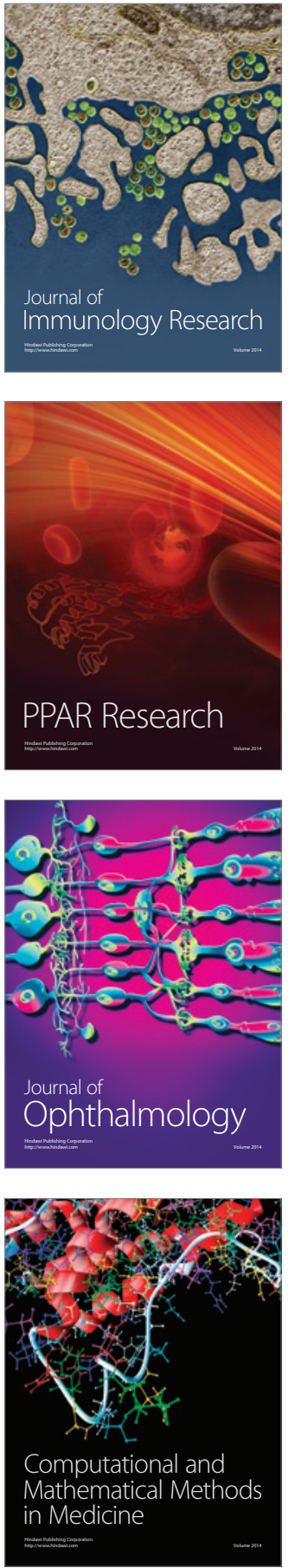

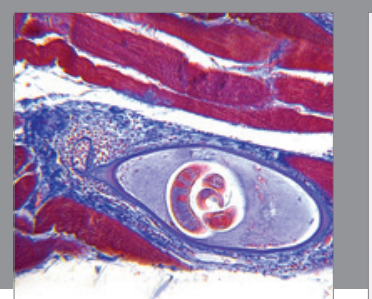

Gastroenterology Research and Practice

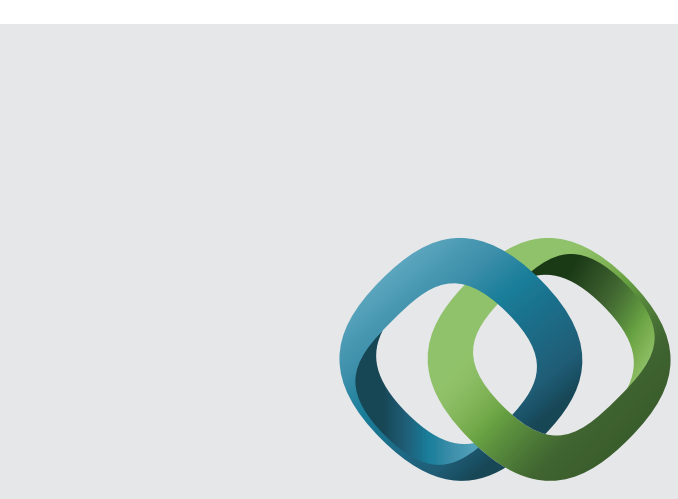

\section{Hindawi}

Submit your manuscripts at

http://www.hindawi.com
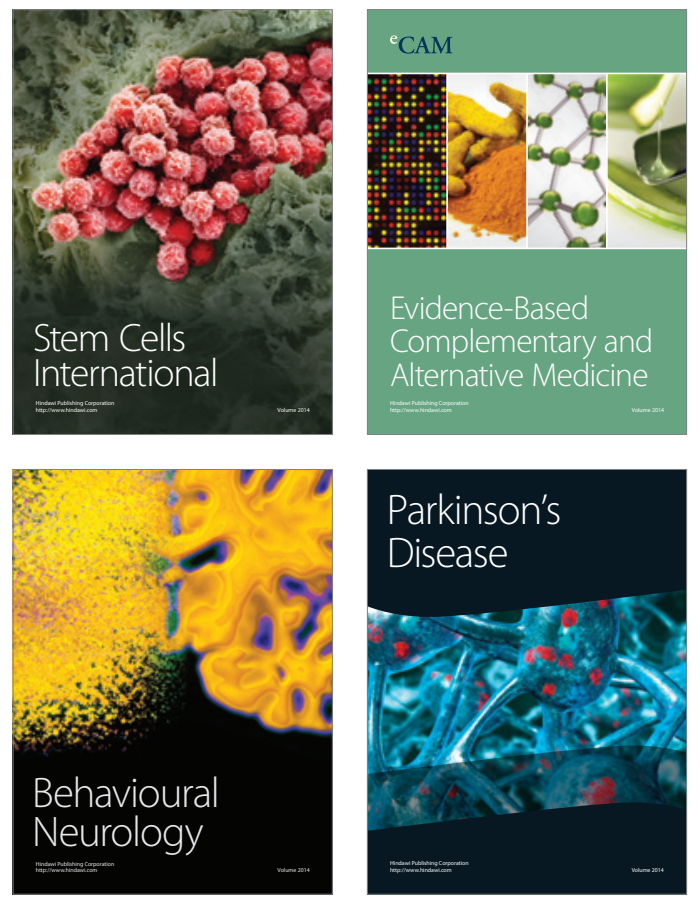
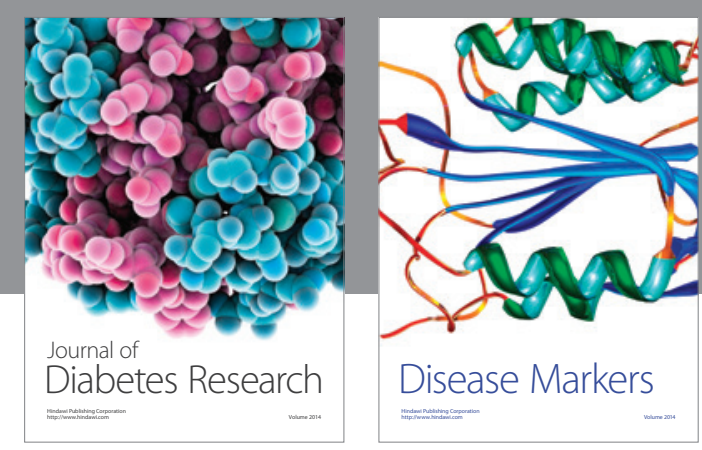

Disease Markers
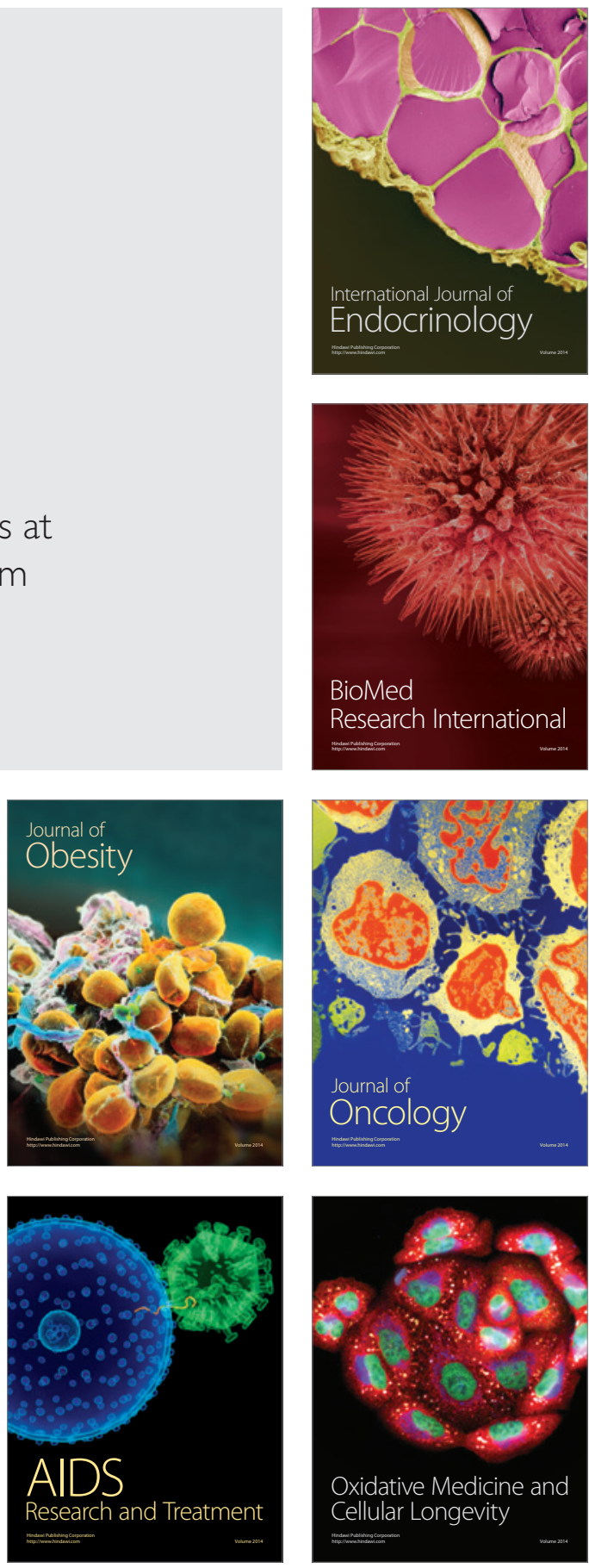